\title{
The Design of a Teaching-Learning Sequence on Simple Machines in Elementary Education and its Benefit on Creativity and Self-Regulation
}

\author{
Germán $\operatorname{Ros}^{1^{*}}$ (D) Arántzazu Fraile Rey ${ }^{1}$ (D) Amelia Calonge ${ }^{2}$ (D), María Dolores López-Carrillo ${ }^{2}$ \\ ${ }^{1}$ Department of Physics and Mathematics, Faculty of Education, University of Alcalá, SPAIN \\ 2 Department of Geology, Geography and Environment, Faculty of Education, University of Alcalá, SPAIN
}

Received 27 July 2021 - Accepted 29 November 2021

\begin{abstract}
In this study, the process of design, implementation, evaluation, and redesign of a TeachingLearning Sequence (TLS) on simple machines for students of 9-12 years old is shown according to the principles of Design Based Research. The aim is to create a TLS that satisfactorily addresses the conceptual difficulties inherent to the object of study and that succeeds in fostering selfregulation skills and creativity. Both qualitative (focus group, semi-structured interviews, students' reports, and teacher's class notes) and quantitative instruments (a validated questionnaire and an ad hoc one with content validation by experts) are used. The statistical analysis of the questionnaires and the narrative analysis of the qualitative instruments have been triangulated. The results show that students manage to address the conceptual and procedural difficulties of the object of study while developing emotional (enjoyment and self-efficacy) and cognitive (metacognition) self-regulation skills, as well as creativity related to the scientific and artisan domains.
\end{abstract}

Keywords: creativity, metacognition, elementary education, self-regulation, simple machines, teaching-learning sequence

\section{INTRODUCTION}

The design-based research approach (Design Based Research Collective, 2003) as a methodology (hereinafter DBR), recognises the importance of both theory and interventions to address educational situations. It aims to generate knowledge about the nature and conditions of teaching and learning. One method of accomplishing this is, among others, the design, implementation, and evaluation of Teaching-Learning Sequences (TLS), which can be understood as interventionist research that generates new didactic knowledge (Kortland \& Klaassen, 2010). Thus, research through TLS aims to address in a more holistic and balanced way the two traditional approaches to research in science and mathematics education, one focused on teaching practice and the scientific content itself, and the other more focused on the students and their difficulties (Duit, 2006). In this direction, the present research shows the process of creation and evaluation of a TLS for elementary education on simple machines, considering both the conceptual difficulties of students and how to address them in the classroom. In addition, we also analyse if the implementation of the TLS fosters the promotion of self-regulation and creativity in the students. Both are embedded within the systemic competencies, which refer to the integration of cognitive abilities, practical skills, and disposition towards the subject under study, that should be fostered throughout the teaching and learning process (Gordon et al., 2009).

\section{THEORETICAL FRAMEWORK}

\section{Teaching-Learning Sequences}

DBR aims to link the major theories on the teachinglearning process with specific conceptual difficulties in real contexts and reducing the gap between research and practice. There are many ways of carrying out design work related to different pedagogical principles. Méheut and Psillos (2004) found, among others, the "didactical structures" (Lijnse, 1995), the "model of educational reconstruction" (Duit et al., 2012), the "two worlds frame" (Buty et al., 2004), the "learning demand design

(c) 2022 by the authors; licensee Modestum. This article is an open access article distributed under the terms and conditions of the Creative Commons Attribution License (http://creativecommons.org/licenses/by/4.0/).

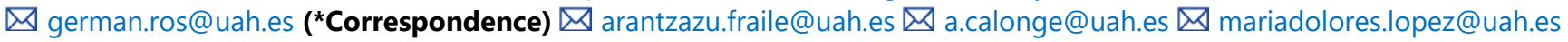




\section{Contribution to the literature}

- This article supports the Design Based Research framework and the Teaching-Learning Sequences (TLS) in particular, as a fruitful tool to go further in connecting research and real school life.

- A TLS on simple machines for elementary education is presented: Conceptual framework, design considerations, conceptual difficulties addressed, evaluation, and redesign.

- Through the analysis of qualitative and quantitative instruments, it is shown that the TLS produces benefits at the conceptual level and fosters creativity and emotional and cognitive self-regulation skills.

tool" (Leach \& Scott, 2002) or the "content-specific theory" (Andersson \& Bach, 2005). Within this diversity, there is agreement that all DBR design follows four major phases (Aranzábal et al., 2021):

A. Theoretical foundation and objectives,

B. Design,

C. Implementation and

D. Evaluation and redesign.

More specifically, Méheut and Psillos (2004) review TLS-based research and its theoretical foundation, defining TLS as "it is both an interventional research activity and a product, like a traditional curriculum unit package, which includes well-researched teachinglearning activities empirically adapted to student reasoning" (p. 516). Therefore, "the TLS must very well link the teaching proposal with the expected learning" (p. 12). The typical process for a TLS-based research is schematized in Figure 1, including the main features of any TLS among which it is worth highlighting (Kortland \& Klaassen, 2010; Psillos \& Kariotoglou, 2015):

- Justify the relevance of the object of study.

- Review the literature on the conceptual difficulties about the topic of study. In this sense, students' previous ideas should be considered as a starting point because of their enormous relevance (Driver, 1985).

- Show the previous decisions and considerations that have been taken when designing the activities and their sequencing.

- Consider the educational curriculum in the design of learning objectives.

- Make evident the didactic transposition (Chevallard, 1989), that is, to show an adequate adaptation to the specific context of the intervention.

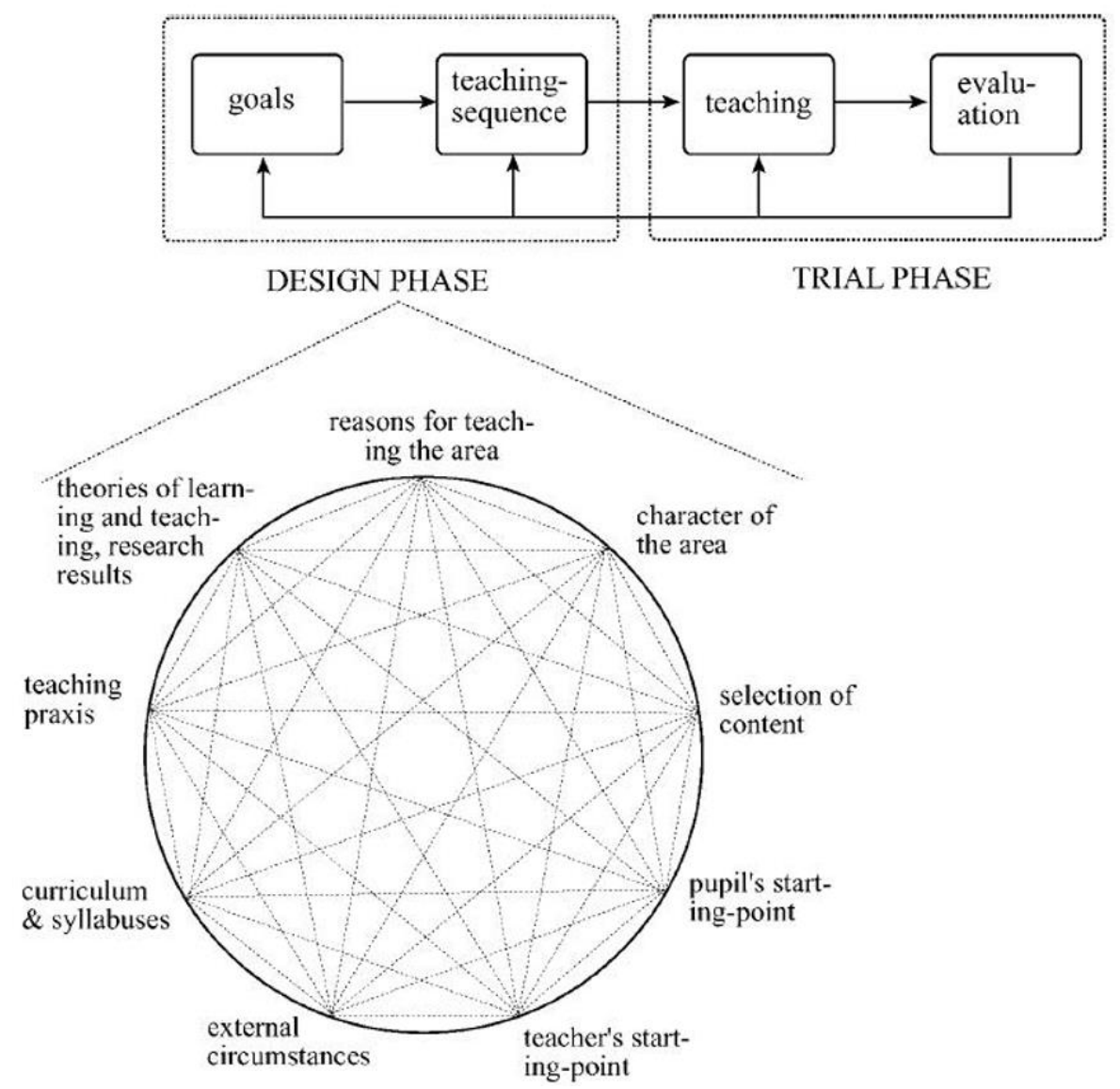

Figure 1. Aspects of the development and study of teaching sequences (taken from Andersson \& Bach, 2005) 
- Make explicit in the design the linkage of each of the teaching-learning activities with the specific aspects of the competencies they demand.

- Show the process of iterative refinement, evaluating, redesigning, and revaluating the results.

- Generate useful products for the teaching community, such as guides or study materials for students.

- Highlight the involvement of different agents: researchers and teachers; and their interaction.

\section{Self-Regulation and Creativity as Systemic Competences}

The European Reference Framework of Key Competences for Lifelong Learning defined eight key competencies (Gordon et al., 2009, p. 44): (1) Communication in the mother tongue, (2) communication in foreign languages, (3) mathematical competence and basic competences in science and technology, (4) digital competence, (5) learning to learn, (6) social and civic competences, (7) sense of initiative and entrepreneurship, and (8) cultural awareness and expression. In addition, the development of these key competencies should be supported by systemic competences, that include research skills, capacity to learn, the ability to adapt to new situations, creativity, understanding other cultures, ability to work autonomously, project design and management, initiative and entrepreneurial spirit, concern for quality and will to succeed (Gordon et al., 2009, p. 54).

The designed TLS fosters the key competence (3) since it is devoted to the development of scientific and mathematical concepts and abilities in the students whose content (simple machines) connects with technology. However, these competences are not mutually exclusive. On the contrary, they are interconnected: "In this increasingly complex world, creativity and the ability to keep learning and innovating will count as much or more than specific areas" (Gordon et al., 2009, p. 87). Therefore, this study analyses also the effect of the implementation of the TLS in two systemic competences, self-regulation (a key element in the ability to learn) and creativity.

The concept of self-regulation of learning is multidimensional. Thus, it comprises aspects related to cognitive self-regulation (or metacognition) and emotional self-regulation related to self-efficacy and positive attitudes (usefulness, enjoyment, value) towards the subject of study (Hattie \& Yates, 2013; Martín, 2020). Metacognitive processes are crucial for self-regulated learning, which involves processes of evaluation of the understanding of the learning objectives, estimation of one's weaknesses and strengths concerning the object of study, selection of strategies to address the proposed problems, planning, execution, and monitoring of the plan and reflection on the entire process (Martín, 2020). Several studies have shown that students who spontaneously use self-explanation and reflection more frequently obtain better academic performance (Chi et al., 1989) and that those who selfevaluate their strategies and modify them when necessary are more effective problem solvers (Bransford et al., 1999). Therefore, it is recommended to educate students about the selection and evaluation of their learning strategies from an early age (McClelland \& Cameron, 2011). In fact, the ability to self-regulate is the main predictor of academic success according to some studies (Gomes et al., 2014).

As regards emotional self-regulation, when students face a challenge, problem, or new situation, the subjective value they assign to it has a decisive influence. It depends on their evaluation of the usefulness of the learning objective and their enjoyment or pleasure with the proposed activities, as well as their expectations of success, which depend closely on their self-efficacy in the proposed task (Martín, 2020). Thus, there is a significant positive correlation between the ability to self-regulate and the sense of self-efficacy (Schunk, 1989). In fact, students with greater metacognitive skills for learning tend to have greater self-confidence in achieving the learning objectives and, therefore, greater motivation to learn (Hattie \& Yates, 2013; Martín, 2020).

Concerning creativity, its conceptual perspective in the field of education includes psychological, behavioural, and sociocultural aspects (Glaveanu \& Begettho, 2020). Thus, creativity could be analyzed from a pluri-perspective vision: The creative person including cognitive and conative traits of the student (Lubart \& Thornhill-Miller, 2019), the creative product (Craft, 2001), the creative process (Sternberg \& Lubart, 1993), the influence of the context and from the domain perspective. The two latter are of special interest here. First, the influence of context on the development of creativity can be highlighted through the relationship between creativity, motivation, and self-efficacy (Conradty et al., 2020) and the relationship between motivation, knowledge, and creative skills (Amabile, 1996). Secondly, various forms of creativity have been described from the domain perspective (Burnard, 2012; Sternberg, 2005). In this sense, three categories of creativity could be described according to the historical and cultural perspective of Glaveanu (2018). First, the artistic creativity characterised by divergent thinking, spontaneity, and originality. Second, the creativity of the scientist manifested in problem solving and convergent and analytical thinking. Finally, the creativity of the artisan shown through the making of objects and the handling of tools. This classification is of great interest to analyze the development of creativity in scientific and technological educational interventions like the one presented here, especially focusing on the last two categories. 


\section{RESEARCH QUESTIONS}

The TLS proposed for the study of simple machines in elementary education involves new dynamics and processes for students, where manipulative and reasoning activities predominate, connecting concepts from different subjects and bringing into play processes of self-regulation (cognitive and emotional) of learning and various forms of scientific and artisan creativity. Therefore, we intend to answer the following research questions:

Q1. How is the process of creation and evaluation of a TLS on simple machines for elementary education according to DBR principles?

Q2. Does the designed TLS promote the development of self-regulation skills and foster various forms of creativity?

Two objectives are stated for each research question, respectively:

O1. Design a TLS following the phases of DBR and taking into account the TLS main features.

O2. Evaluate the benefits on the conceptual understanding of the students.

O3. Analyze the effect of the TLS in metacognition, self-efficacy and the generation of positive attitudes towards science.

O4. Study the influence of the TLS in the development of scientific and artisan categories of creativity.

\section{METHODOLOGY}

DBR gives high importance to the involvement of teachers in research, creating communities of practitioners and fostering partnerships between university researchers and schoolteachers. From that epistemological principle, researchers, teachers and students have been involved in a mixed and multimethod research project (Levy, 2017). In the iterative implementation and evaluation of the TLS, a spiral process between theory and practice was developed (Elliott, 2009), with the aim of bringing research closer to the actual practice, convinced of the importance of understanding educational reality from the inside.

As a consequence to the complexity of learning situations, it is necessary to collect several records to capture the whole process and to consider all the actors involved (Design-Based Research Collective, 2003; Plomp \& Nieveen, 2007): Students, teachers, and researchers. Likewise, it is necessary to take note of the decisions taken in a justified manner, to give a detailed description of the evolution of the TLS, as well as to evaluate it and ensure its quality (Cobb \& Gravemeijer, 2008). Therefore, qualitative and quantitative approaches are combined and complemented, developing a mixed method research (Creswell \& Creswell, 2017).

Following the major four phases of every DBR design and considering the main features of the creation of a TLS, the research process is described next:

1. Epistemological analysis of relevant issues within the topic of study.

2. Analysis of textbooks and official curriculum, in particular the specific contents and learning objectives.

3. Enquiry about the conceptual difficulties encountered by students of elementary education.

4. Creation of a focus group between researchers and teachers. Fundamental criteria were established for the creation of the TLS. First, to address these conceptual difficulties, establishing the prioritisation of manipulative activities and their sequencing criteria. Second, taking special care that the activities involve cognitive and emotional self-regulation strategies as well as the development of diverse creativities.

5. Creation of the initial version of the TLS consistent with the theoretical framework described above.

6. Two Iterative implementation and evaluation of the TLS. Evaluation involves the initial working group and the students' teachers. Reworking some aspects of the TLS and deepening the underlying theoretical framework.

7. Implementation of the final version of the TLS with a third group of students (3rd iteration).

8. Data collection: students' reports, teacher's class notes, interviews with both groups and the questionnaires filled by the students.

9. Statistical analysis of the questionnaires using $R$ statistical software (R Core Team, 2018) and the narrative analysis of the qualitative instruments have been triangulated to answer the research questions.

\section{Participants}

The participants in this research were:

- Researchers in science and mathematics education (4) dedicated to the design of the TLS, the coordination of the implementation process, revision and evaluation of the results. On several occasions, researchers also participated in the lectures, collaborating with the teachers and completing the field notes.

- One group of elementary education teachers (3) participated in the focus group with researchers for the design and evaluation of the TLS.

- A second group of elementary school teachers (3) were in charge of the classroom intervention and 
participated in the semi-structured interviews for the evaluation of the final version of the TLS.

- Experts (9) in quantitative research for the validation of the questionnaire.

- Students (116) from 9 to 12 years along the three iterations. The questionnaires to evaluate the final version of the TLS were completed by the 50 students that participated in the last iteration and 10 of them also joined to a semi-structured interview.

The implementation was carried out in two different schools (the first two iterations in two classrooms in one school and the final version of the TLS in the other one) of a medium-high socio-economic level. These schools were selected because they are located in two different regions where the content of simple machines is taught at different ages and due to previous successful collaboration between the researchers and the schoolteachers. Although there were students with diverse academic development levels, there were no cases of high learning difficulties. All the students were native speakers.

\section{Instruments}

The instruments used in this research are described next along with the research objectives that allow to address:

- Focus group formed by researchers and elementary education teachers. They agreed on the methodological bases of the intervention, designed and reviewed the activities (O1 and O2).

- Student reports. The students' answers to the planned activities included in the TLS were analysed (O2).

- Teachers' class notes (O2).

- Semi-structured interview with the teachers and students involved in the implementation of the final version of the TLS (O2, O3, and O4).

- STEM Semantics Survey (Tyler-Wood et al., 2010). The dimension referring to Science was selected. This questionnaire was chosen because of its simplicity (use a dichotomous scale) and the fact that it is widely used in the literature. The students complete the sentence "To me, Science is ...." and choose between two opposite adjectives (Table 1). It was translated into Spanish following a process of translation and back-translation with the help of two English language experts (O3).

- An ad-hoc questionnaire was designed with four dimensions: Enjoyment, creativity, self-efficacy, and metacognition (Table 2). Few items are included in each dimension since it is aimed at elementary school students, also using a simple language. (O3 and $\mathrm{O} 4)$.
Table 1. STEM semantic survey. Dimension: Science (TylerWood et al., 2010). "To me, science is ..."

\begin{tabular}{cc}
\hline \multicolumn{3}{c}{ Adjectives } \\
\hline Fascinating & Mundane \\
Appealing & Unappealing \\
Exciting & Unexciting \\
Means nothing & Means a lot \\
Boring & Interesting \\
\hline
\end{tabular}

Table 2. Designed questionnaire and content validity index of each item. The students indicate their agreement with the sentences ( 1 minimum agreement - 5 maximum agreement)

\begin{tabular}{|c|c|c|}
\hline \multicolumn{2}{|c|}{ Code Item } & \multirow[t]{2}{*}{$\mathrm{CVI}$} \\
\hline & Enjoyment & \\
\hline$\overline{\mathrm{E} 1}$ & I found the activity very attractive & .84 \\
\hline E2 & I had fun and enjoyed the proposed activities & .85 \\
\hline \multirow[t]{2}{*}{ E3 } & $\begin{array}{l}\text { I would like to continue learning in this way in } \\
\text { the future }\end{array}$ & .99 \\
\hline & Self-efficacy & \\
\hline$\overline{\text { S1 }}$ & I have felt able to perform the proposed tasks & .88 \\
\hline S2 & $\begin{array}{l}\text { I have been able to make decisions when doing } \\
\text { the activities }\end{array}$ & .82 \\
\hline \multirow[t]{2}{*}{ S3 } & I felt that I could work with autonomy & .90 \\
\hline & Metacognition & \\
\hline M1 & $\begin{array}{l}\text { I realized what was clear to me and what was } \\
\text { not }\end{array}$ & .91 \\
\hline M2 & $\begin{array}{l}\text { I realized the mistakes I was making and tried } \\
\text { to fix them }\end{array}$ & .90 \\
\hline \multirow[t]{2}{*}{ M3 } & $\begin{array}{l}\text { I think I learn more by working in this way } \\
\text { than in the usual way }\end{array}$ & .85 \\
\hline & Creativity & \\
\hline $\mathrm{C} 1$ & $\begin{array}{l}\text { During the activities, I acted like a scientist: } \\
\text { experimenting }\end{array}$ & .86 \\
\hline $\mathrm{C} 2$ & $\begin{array}{l}\text { During the activities, I acted like a scientist: } \\
\text { making hypotheses }\end{array}$ & .87 \\
\hline $\mathrm{C} 3$ & $\begin{array}{l}\text { During the activities, I acted like a scientist: } \\
\text { drawing conclusions }\end{array}$ & .86 \\
\hline $\mathrm{C} 4$ & $\begin{array}{l}\text { I enjoyed creating things with my hands and } \\
\text { seeing them work }\end{array}$ & 1 \\
\hline
\end{tabular}

The designed questionnaire uses a Likert scale (1 minimum agreement - 5 maximum agreement). The content validation of the questionnaire was performed by nine experts who are researchers in the educational field following the next process:

i. Experts self-assessment (Ramírez \& Cepena, 2012): The expert's competence coefficient (between 0 and 1) is determined based on the expert's opinion of their level of knowledge of the research problem, as well as the sources that allow them to argue the established criterion. A minimum value of competence coefficient of .75 is established to consider the experts suitable for the validation process. In our case, three of the nine pre-selected experts were discarded.

ii. Item review: Following the comments of the experts some items were discarded because they do not correspond with the dimension they 
intended to measure (for example, "I believe that what I have learnt will be useful in the future" from self-efficacy and "I felt guided by the teachers" from enjoyment dimension respectively). Besides, items $\mathrm{C} 1, \mathrm{C} 2$, and C3 were separated when they were previously combined into one.

iii. Content validity: The selected experts assessed (from 1 to 4 ) each item according to the criteria of clarity, sufficiency, relevance, and coherence, based on predefined criteria (Escobar-Pérez, \& Cuervo-Martínez, 2008). The item content validity index (CVI) is computed as the quotient between the total sum of points obtained by an item and the maximum possible number of points (see Table 2). Usually, a CVI index of greater than .80 is a high value which denotes a high level of agreement (Sangoseni et al., 2013). All the items passed this criterion.

Regarding the reliability of the questionnaire, Cronbach's alpha ( $\mathrm{a}$ ) is calculated. We obtain values of $.70, .74, .56$, and .74, respectively in the dimensions of enjoyment, self-efficacy, metacognition, and creativity. The results show good reliability, only smaller than the usual standards for the metacognition dimension but, given the small number of items, the result could be considered valid (Loewenthal \& Lewis, 2018).

\section{Ethical Issues}

The different participants in the study, i.e., the students and teachers gave informed consent to participate in the study and the interviews, receiving all the relevant information beforehand. The study was conducted with the approval of all educational institutions involved in the study.

\section{RESULTS}

\section{The Designed TLS}

One of the fundamental objectives of all design research is to generate useful products for the teaching community (Kortland \& Klaassen, 2010; Psillos \& Kariotoglou, 2015). The TLS proposed here has followed in its creation the phases described previously. The overall process is summarized in Figure 2 (according to the theoretical model shown in Figure 1) and details are given next.

\section{Theoretical basis}

The first phase starts with the theoretical foundation about the object of study (simple machines). In this case, we propose to address the content of simple machines in elementary education. The choice is due to several factors. The contents and procedures to be developed allow enhancing scientific competence (García-Carmona
\& Criado, 2013), connecting science, mathematics, and technology, fostering conceptual and procedural skills (psychomotor and motor skills), bringing the student closer to the use of a language closer to the scientifictechnological one. Competencies related to the design and planning of tasks are fostered, "the development of emotional commitment to technological thinking, in the sense that schoolchildren adopt an active and entrepreneurial attitude" (Criado García-Legaz \& García-Carmona, 2011). Moreover, it is omnipresent content in the daily environment of schoolchildren, which makes it possible to connect ideas with their reality and thus achieve more meaningful learning. On the other hand, it is a basic content within the subject of Natural Sciences in Spain, although it is taught in different courses in different regions between 9-12 years of age (although simple, everyday examples are already mentioned before at around 7-8 years old). This is an important element to be considered in the design and evaluation of the TLS. Finally, it is a propaedeutic content, as it will allow students to be introduced to technology education that will be extended in Compulsory Secondary Education.

Next, an exhaustive literature review has been carried out on the conceptual difficulties (CD) of students in this subject, among which it is worth mentioning the following (American Institute of Physics, 1998; García-Carmona \& Criado, 2013; García-Legaz \& García-Carmona, 2011; Lherer \& Schaule,1998; Norbury, 2006):

- CD1: Very early ages (6-8 years) students refer only to machines very close to their everyday environment, starting a certain level of abstraction between 8-10 years.

- CD2: Scarce identification of simple machines in their environment.

- CD3: Difficulties in understanding that in a gear, its direction and speed of rotation depending on the gears connected to it and their different radii or number of teeth.

- CD4: Difficulties in understanding that belts and gears not only serve to transmit motion but also forces.

- CD5: Difficulties relating the force applied to the pedals of a bicycle to the distance it moves per pedal stroke.

- CD6: They do not assimilate the key concept of mechanical advantage until they are 10-12 years old.

- CD7: Students present difficulties in understanding what mechanical advantage implies in the case of pulleys or gears, only being evident in the case of levers. 


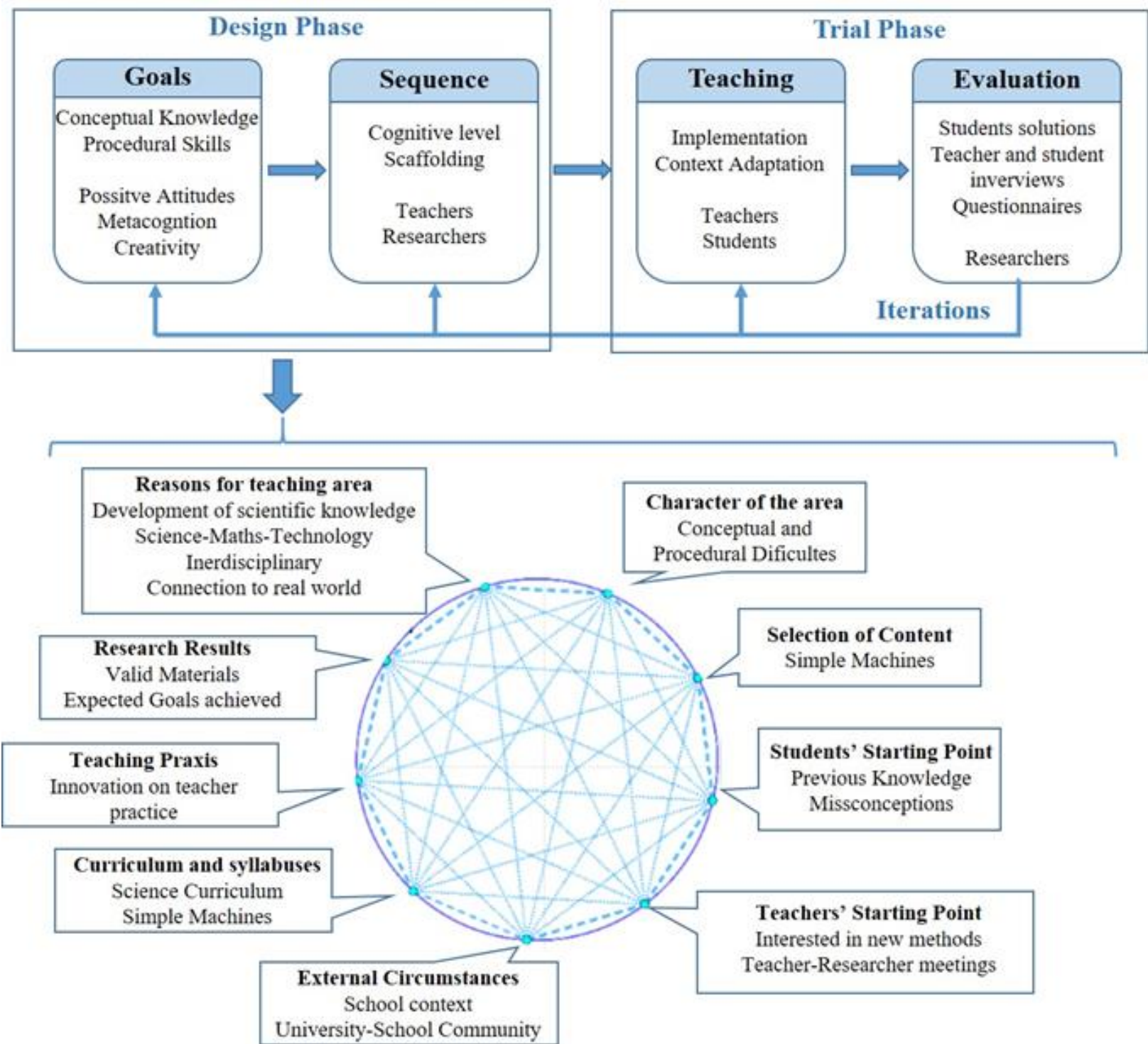

Figure 2. Development and study of the proposed teaching-learning sequence in accordance with the model by Andersson \& Bach (2005) shown in Figure 1

- CD8: Lack of understanding about the absence of mechanical advantage in a fixed pulley versus the advantage presented by a mobile pulley.

- CD9: There is no evidence that schoolchildren are aware that the mechanical advantage of mechanical operators is a consequence of the principle of conservation of energy.

- CD10: Believing that machines put out more work than we put in. Not realizing that machines simply change the form of the work we do (i.e., the trade-off force for distance or distance for force).

- CD11: Most books that discuss simple machines emphasize mechanical advantage rather than work or energy.

The last three involve more complex concepts and, as will be indicated later, they are addressed in activities that are only dedicated to older students. In addition, other procedural difficulties (PD) have been found that are also addressed in the TLS:
- PD1: Manipulative difficulties and lack of fine psychomotor skills.

- PD2: Reading measuring devices.

- PD3: Representation and organization of information.

\section{Design}

The learning objectives are specified, and the activities are designed and sequenced based on the consideration of the age of the students (9-12 years old), the contents specified in the official syllabus, and the conceptual difficulties already analyzed.

In addition to generating authentic and meaningful knowledge, the TLS aims to influence the development of positive attitudes, metacognition, and creativity of students. Therefore, it has been decided to give special relevance to manipulative activities through experiences. These have several benefits (Jiménez, 2006) 
as, for example, the construction or generalization of knowledge, the communication of results and conclusions, the development of positive attitudes towards scientific-technological knowledge, the improvement of the understanding of the generation of scientific knowledge itself (nature of science), involving the ability to plan and use procedures for problemsolving. The hands on process in which the learner is immersed allows an internal dialogue to be established between what the learner is manipulating and constructing and the internalisation or appropriation that takes place in his or her head, all together favouring metacognitive processes.

The sequencing of the activities of the TLS considers the cognitive development of students according to the categorization of Shayer and Adey (1981). Therefore, some activities are reserved only for the higher grades where the student will have safely reached the advanced concrete stage (10-14 years). Scaffolding criteria were also considered to sequence the activities in initial exploration, modelling, synthesis, and generalization (Sanmartí, 2002), although the latter at a basic level as it is elementary education. Finally, the development of the worksheets and experiments is set up through guiding questions, which is an important aspect to guide the students' learning and therefore, according to several authors, should guide the structuring and sequencing of the activities and tasks of the TLS (Edelson, 2001; Krajick et al., 2008).

In the whole design phase, the participation of elementary school teachers has been very relevant both to assess the adequate didactic transposition and the sequencing of activities and their adequacy to the curriculum.

The TLS begins with an inquiry question: How were the Great Pyramids built in Ancient Egypt? In the discussion, the students themselves bring up the use of wheels, ramps, and pulleys, which allows us to focus and conceptualize the problem: How do machines help us? Another study using a similar starting point under a STEM approach following an inquiry process and analyzing the effect on student attitudes can be found in Toma and Greca (2018).

Appendix A shows the expected learning objectives that cover those of the Natural Sciences subject of this topic and some of the mathematics subjects. In Spanish elementary education there is no specific subject of Technology, but its competencies are assumed to be included in Natural Sciences and Mathematics, so we have added some specific objectives as well as others of an attitudinal nature

\section{Implementation}

The intervention was carried out in three iterations. As mentioned above, in Spain the topic of simple machines is in different courses depending on the

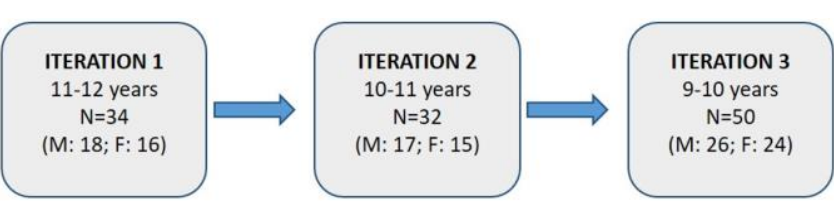

Figure 3. Number of students in each iteration, age, and gender

regions, so it was decided to start with the higher ages and reduce in the following iterations (see Figure 3) so that the conceptual level was adapted to the various groups. Some activities are indicated as suitable only for students in higher grades. Thus, the final TLS is adaptable to this diversity.

During the implementation several data is collected such as students' reports and teacher's class notes. At the end of the third one, the interviews with the students and their teachers were performed and the students complete the questionnaires.

\section{Evaluation and redesign}

In this stage, the TLS is evaluated to check its effectiveness concerning the learning objectives established and the conceptual difficulties addressed. Since it is an iterative process, modifications have been made during each iteration and some activities have been redesigned. Thus, the TLS has been empirically validated considering both the quality of the sequence and the learning achieved (Plomp \& Nieveen, 2007). The internal coherence of the TLS was positively evaluated by the teachers and researchers of the focus group.

Appendix B shows the final design of the TLS that requires 12 sessions of 45-60 minutes. The different activities are briefly explained, connected to the contents and learning objectives. The conceptual and procedural difficulties considered in each activity are also shown.

Appendix $C$ shows the most relevant modifications made throughout the evaluation and redesign after each iteration. These changes include rewriting some questions and activities to better adjust to the level of the students and/or to address certain conceptual errors detected in the in the two first iterations, changing materials to facilitate the measurement process, adding some more creative activities and explanatory videos to help teachers in their explanations.

During the interviews after the third iteration, the students' highlight how they have indeed managed to address many of the conceptual difficulties intended in the design phase and link these contents with everyday contexts and usefulness of science in real life:

Student 2: "I liked the belts because I discovered that there are many around us." (CD1, CD2).

Student 6: "I liked the pulleys because I found it curious that with a little bit of force you can lift a lot of weight." (CD7). 
Student 1: "With the experiments, it was easier to understand and more fun." (CD6).

Student 3: "I thought the machines had nothing to do with each other, but I was surprised to see that they had a lot in common." (CD6).

Student 2: "Pulleys, levers, and inclined plane allow you to lift with less force." (CD6, CD7).

Student 8: "Examples like the jaw, scissors, an elevator, a spiral staircase, and a screw helped us understand." (CD1, CD2).

On the other hand, students have expressed difficulties in the manipulative part and in making measurements. The fact of carrying out the learning process experimentally has undoubtedly allowed these difficulties to emerge, which can only be overcome through practice:

Students 3, 5, and 8: "It was difficult for me to assemble and operate the pulleys." (PD1).

Students 1, 2, and 6: "It was difficult to assemble the Lego sets." (PD1).

Students 6 and 7: "I had a hard time using and understanding the dynamometer." (PD2).

In addition, the students have expressed a certain degree of overwhelm in some activities and reluctance to fill out the worksheets, and some difficulties inherent to teamwork:

Student 2: "I was feeling overwhelmed with the time and fed up with worksheets."

Student 2: "A little nervous because it took a long time to assemble the gears."

Student 4: "I was looking forward to seeing how the machines worked but I was overwhelmed finishing the worksheets and my group was getting angry and not in agreement."

In this regard, we have tried to extend the duration of the last sessions and reduce some of the questions on the worksheets, although it is considered necessary and important to promote written expression and joint reflection by the group during the activities.

As for the opinion of the teachers who carried out the intervention, they value very positively the manipulative and experimental part of the process, as well as the high level of motivation and participation achieved in the students. On the other hand, they also highlight some other considerations:

Teachers 1 and 2: "I lacked a previous explanation before the experiments."
Table 3. STEM semantic survey. Dimension: Science. Percentage of responses

\begin{tabular}{cccc}
\hline Adjectives & $\%$ & Adjectives & $\%$ \\
\hline Fascinating & 98 & Mundane & 2 \\
Appealing & 94 & Unappealing & 6 \\
Exciting & 100 & Unexciting & 0 \\
Means nothing & 0 & Means a lot & 100 \\
Boring & 8 & Interesting & 92 \\
\hline
\end{tabular}

Teacher 1: "Since the workshop has been given to me, it does not motivate me as much as doing it myself."

Teacher 2: "I didn't feel very involved in the making of the worksheets."

The first comment has to do with the fact that the TLS promotes a teaching-learning process that begins first with experimentation and inquiry, and then moves on to abstraction and conceptualization. This approach, from manipulative to abstraction, is widely recommended in science and mathematics education (Bruner, 1996; Bybee et al., 2006; Sinha \& Kapur, 2021). The teachers' comments reflect their more traditional conception where they tend to start with ideas and concepts and then move on to their application. The other comments highlight a potential problem for the DBR framework and the TLS methodology in particular, since the TLS is designed and tested in a specific context but will also be used in other ones. In this sense, the DBR framework proposes that the activities should be sufficiently open for their application in different contexts, leaving freedom of action to the teacher.

Another comment from the teachers that came up recurrently in the activity was that "They would have worked better in pairs" (Teachers 1, 2, and 3). Indeed, the TLS activities were designed to be carried out mostly in pairs, whereas in this case they were usually done in larger groups but with little interaction among the students. The reason was the health conditions in the schools due to COVID-19. In any case, as we have seen, this fact did not significantly affect the research.

\section{SELF-REGULATION AND CREATIVITY}

The results of the STEM Semantic Survey and the designed questionnaire are shown in Table 3 and Table 4. The distribution of responses does not follow a Gaussian distribution as tested by the Shapiro-Wilk test. Therefore, non-parametric methods (Mann-Whitney U) are used to analyze the possible existence of significant differences. Thus, no significant differences by sex were found, so the results are shown as aggregate.

These results corroborate from the students' point of view the fact that the TLS has promoted their emotional self-regulation and the development of positive attitudes towards science. Thus, enjoyment dimension shows very high results with median in the maximum value (E1, E2, 
Table 4. Designed questionnaire. Percentage of responses in a Likert scale (1 minimum - 5 maximum agreement). Crobach's alpha $(a)$ of each dimension is shown. The position of the median is marked in bold

\begin{tabular}{|c|c|c|c|c|c|c|}
\hline & & 1 & 2 & 3 & 4 & 5 \\
\hline \multicolumn{7}{|c|}{ Enjoyment $(a=.70)$} \\
\hline$\overline{\mathrm{E} 1}$ & I found the activity very attractive. & 6 & 2 & 4 & 28 & 60 \\
\hline E2 & I had fun and enjoyed the proposed activities. & 2 & 0 & 10 & 4 & 84 \\
\hline E3 & I would like to continue learning in this way in the future. & 2 & 0 & 8 & 20 & 70 \\
\hline \multicolumn{7}{|c|}{ Self-efficacy $(a=.74)$} \\
\hline S1 & I have felt able to perform the proposed tasks. & 2 & 8 & 16 & 48 & 28 \\
\hline S2 & I have been able to make decisions when doing the activities. & 4 & 8 & 18 & 44 & 26 \\
\hline S3 & I felt that I could work with autonomy. & 2 & 4 & 26 & 38 & 30 \\
\hline \multicolumn{7}{|c|}{ Metacognition $(\alpha=.56)$} \\
\hline$\overline{\mathrm{M} 1}$ & I realized what was clear to me and what was not. & 6 & 6 & 26 & 42 & 20 \\
\hline M2 & I realized the mistakes I was making and tried to fix them. & 2 & 2 & 34 & 36 & 26 \\
\hline M3 & I think I learn more by working in this way than in the usual way. & 2 & 4 & 14 & 18 & 62 \\
\hline \multicolumn{7}{|c|}{ Creativity $(\alpha=.74)$} \\
\hline $\mathrm{C} 1$ & During the activities, I acted like a scientist: experimenting. & 2 & 10 & 18 & 34 & 36 \\
\hline $\mathrm{C} 2$ & During the activities, I acted like a scientist: making hypotheses. & 8 & 10 & 20 & 32 & 30 \\
\hline $\mathrm{C} 3$ & During the activities, I acted like a scientist: drawing conclusions. & 2 & 6 & 14 & 50 & 28 \\
\hline $\mathrm{C} 4$ & I enjoyed creating things with my hands and seeing them work. & 4 & 2 & 2 & 12 & 80 \\
\hline
\end{tabular}

and E3) and also a very high feeling of self-efficacy (S1, S2, and S3). In addition, the results of the STEM Semantic Survey are conclusive with percentages higher than $90 \%$ on the positive side of the dichotomous scale in every item that shows a very strong motivation during the activities. This is also corroborated in the interview performed by both students and teachers:

Student 1: "I was excited to see the results of the experiments."

Student 3: "I felt proud because, although it was difficult, I managed to do things."

Student 3: "I felt good, and I worked well with my group alternating what we were doing."

Student 8: "Before I was bored, but now I like it more."

Student 2: "These activities make me like the subject of Natural Science more."

Teacher 2: "The students enjoyed it and had a really good time."

Student 3: "What we learn this way is more useful because now I can see it in everyday life."

Student 2: "Now I know that machines can solve a lot of things."

Student 8: "I found the inclined planes very useful and also the gears."

Student 3: "Indeed, I liked doing it with the experiments and I find it easier to understand."
Teacher 1: "They learn much better by manipulating."

Teacher 3: "Because of the characteristics of my students [several with attention and/or reading comprehension difficulties], I think they learn better from manipulative activities."

Regarding metacognition, the experimental work, the scaffolding process of the activities, and the approach from the manipulative to abstraction have also been positively valued by the students. In the questionnaire they strongly emphasize that during the process they knew clearly what they were doing and their mistakes, and tried to correct them, affirming that they learn more following the applied method (M1, M2, and M3). The interviews also support these findings:

Student 4: "Now I spend all day thinking about why things happen."

Student 3: "It made you think, with the experiments you saw it better and clearer."

Student 7: "Now I wonder what it would be like to make things, how he came up with this invention, and what it could be used for."

Student 4: "Other times when you have doubts, they explain them to you, but this way when you come to a doubt you can experiment yourself to understand it well."

Student 1: "I like it better because at the beginning you don't understand it, but then you do it and you can experiment by yourself." 
Table 5. Correlation (Spearman's rho) between the items of the questionnaire $\left({ }^{*} \mathrm{p}<.01 ;{ }^{* *} \mathrm{p}<.001\right)$

\begin{tabular}{|c|c|c|c|c|c|c|c|c|c|c|c|c|c|}
\hline & E1 & E2 & E3 & S1 & S2 & S3 & M1 & M2 & M3 & C1 & $\mathrm{C} 2$ & C3 & $\mathrm{C} 4$ \\
\hline$\overline{\mathrm{E} 1}$ & -- & & & & & & & & & & & & \\
\hline E2 & $.38^{*}$ & -- & & & & & & & & & & & \\
\hline E3 & 0.25 & .24 & -- & & & & & & & & & & \\
\hline S1 & $.53^{* *}$ & $.50^{* *}$ & $.41^{*}$ & -- & & & & & & & & & \\
\hline S2 & $.38^{*}$ & .27 & .29 & .30 & -- & & & & & & & & \\
\hline S3 & .31 & $.41^{* *}$ & .33 & $.54^{* *}$ & $.52^{* *}$ & -- & & & & & & & \\
\hline M1 & $.47^{* *}$ & $.51^{* *}$ & .13 & .22 & .29 & .24 & -- & & & & & & \\
\hline M2 & .10 & .17 & .20 & .19 & .08 & .27 & $.37^{*}$ & -- & & & & & \\
\hline M3 & $.47^{* *}$ & .05 & $.38^{*}$ & .08 & .29 & .09 & .27 & .02 & -- & & & & \\
\hline C1 & .35 & $.41^{*}$ & .31 & $.41^{* *}$ & $.40^{*}$ & $.52^{* *}$ & $.42^{*}$ & .34 & .17 & -- & & & \\
\hline $\mathrm{C} 2$ & .36 & $.37^{*}$ & .19 & .22 & $.53^{* *}$ & .28 & $.46^{* *}$ & .07 & .23 & $.57^{* *}$ & -- & & \\
\hline C3 & .10 & .05 & .31 & .13 & .36 & .33 & .24 & .37 & .17 & .36 & .15 & -- & \\
\hline $\mathrm{C} 4$ & $.48^{* *}$ & $.50^{* *}$ & .24 & .32 & .32 & $.44^{*}$ & $.50^{* *}$ & .17 & .18 & $.43^{*}$ & $.50^{* *}$ & .20 & -- \\
\hline
\end{tabular}

Student 2: "Now they haven't explained it to us, but we have been able to discover it ourselves."

Teacher 3: "They have developed a high level of metacognition."

Finally, at the creative level, students value very positive aspects of scientific creativity such as experimentation, formulation of hypotheses and making a draw for conclusions, but even more, those aspects related to artisan creativity as building the experiments and testing their operation. Thus, the various participants stated:

Student 6: "We have worked like scientists using machines."

Student 7: "We have learned a little more about how scientists work."

Student 3: "If a problem comes up now, I know I can solve it."

Teacher 2: "Some were able to go further and draw conclusions on their own."

Teacher 3: "In the creation of the catapults the students showed a lot of creativity."

Here, however, the teachers pointed out some concerns:

\section{Teacher 1-2-3: "The material was too scripted."}

Teacher 1-3: "Yes, I indeed associate creativity more with the artistic and the freedom to do something [rather than the scientific and artisan creativities worked in the TLS]."

Teacher 1-2-3: “By technology I usually mean communication and information technologies [ICTs]."

On the one hand, the intervention indeed guides the teaching-learning process to confront and overcome conceptual errors and to cover the contents of the educational curricula. In this sense, additional suggestions for more open-ended and complementary additional activities have been included in the final TLS to be carried out at the teacher's convenience (simulators, videos, and construction of other simple machines). On the other hand, teachers show a concept of creativity joined to the students' autonomy, a very relevant but not unique aspect, and a sense of technology constrained to ICTs. They show little appreciation of the artisan and scientific creativities which are very related to engineering and technology (Glaveanu, 2018) together with the ability to come up with different solutions to the same problem (NCTM, 2000, p. 354; Polya 2004; Silver, 1997).

The level of correlation between the different items of the questionnaire has been determined by using Spearman's rho valid for non-Gaussian and nonsymmetrical distributions as in this case (Table 5). A positive correlation has been found between all of them as expected. The correlations that are statistically significant are highlighted. A strong correlation is observed between many of the items belonging to the dimensions of enjoyment and self-efficacy, showing that the fact of enjoying an activity and feeling capable of it are closely linked, which again highlights the value of considering an adequate scaffolding and a correct didactic transposition in the design of the TLS.

The willingness to keep on learning with this method (E3) strongly correlates with the fact that they think they learn more (M3) and that they feel capable of achieving the proposed tasks (S1). At the metacognitive dimension, several of the items correlate strongly with items of the enjoyment dimension, showing that having clear goals to achieve (M1) and being able to correct mistakes (M2), produces a feeling of satisfaction and enjoyment (E1, E2). Finally, the items related to scientific $(\mathrm{C} 1, \mathrm{C} 2)$ and artisan (C4) creativities correlate strongly with each other, which is likely influenced by the fact that in the proposed TLS scientific concepts are approached from the experimental and manipulative activities. The 
development of the artisan dimension of creativity (C4), closely related to the manipulative and experimental and linked to the typical skills of technology and engineering, is revealed as an engine to capture the attention and motivation of students (E1, E2), promoting autonomy (S3) and metacognition (M1).

The students in the interviews also highlight these correlations between manipulative activities, the development of diverse creativities, and enjoyment:

Student 4: "If I experimented all the time like in these activities, Science would be my favourite subject."

Student 3: "I felt like a real scientist experimenting and I felt good, a lot of fun."

Student 7: "If you can handle it and assemble it yourself, I like it even more."

In summary, the qualitative analysis through the interviews and the quantitative analysis of the questionnaires has revealed the benefits of TLS at the motivational, emotional and cognitive self-regulation levels, as well as the development of diverse creative abilities.

\section{CONCLUSIONS}

This article shows the process of creation, design, implementation, evaluation, and redesign of a TeachingLearning Sequence according to the basic principles of Design Based Research: Starting from the students' conceptual errors, designing activities that address them effectively and within an adequate didactic transposition, making an iterative process of evaluation and redesign, all in collaboration with teachers. In addition, worksheets for the students, teaching guides, and video tutorials have been generated for each of the class sessions and activities, a key element to expand the number of schools that can develop this TLS. The science elementary school teachers have also participated in the design process, assessing the adequate didactic transposition and cognitive level of the activities and its sequencing, as well as their adaptation to the curriculum. In this way, the TLS connects the didactic and pedagogical principles that guide its design with real classroom teaching, the goal of DBR.

The success of the TLS is evaluated by proving that it addresses the more common conceptual difficulties, an indispensable requirement for validation (Leach et al., 2009), that it is very little covered by school textbooks at least in Spain (Pérez \& Villagrá, 2020). In addition, it covers the necessary curricular content, connecting student learning with real problems and situations through experimentation and manipulation, a practice that is also very scarce in the classroom (Pérez \& Villagrá, 2020).
The triangulation of the teachers' opinion, the students' perception and the evaluation of the whole process by the researchers, has been carried out through by using qualitative and quantitative tools. Thus, it is shown that the implementation of the TLS encourages both the development of students' emotional selfregulation, in terms of fostering positive attitudes such as enjoyment and usefulness of what they have learned, and their feeling of self-efficacy, as well as at the cognitive dimension through reflection and selfevaluation strategies. Finally, this TLS based on experimental activities has achieved the development of diverse creativities, eminently scientific and artisan, connecting science and mathematics with engineering and technology. All this is according to the framework of the key and systematic competencies established for the 21st century (Gordon et al, 2009).

As possible future lines of work, we consider the extension of the TLS to secondary education, going deeper into the fundamental laws of energy conservation and the concept of work, as well as the transmission of force and velocity in compound machines.

Finally, this work supports the Design Based Research framework in general and the TeachingLearning Sequences in particular, as a fruitful tool to go further in connecting research and real school life.

Author contributions: All authors have sufficiently contributed to the study, and agreed with the results and conclusions.

Funding: This work has been developed thanks to the CM/JIN/2019-024 project funded from Comunidad de Madrid and Universidad de Alcalá.

Acknowledgements: The authors wish to thank to the external experts who have collaborated to validate the questionnaires and to the staff of the Physics Lab (Jesús García-Bueno) for his help with the production of the materials. The authors especially thank to the rest of the members of the "Build, Research, Create" group of the Alcalá University, teachers (Ana, Marta, Nuria and Laura) and principal of C.E.I.P. San Ignacio de Loyola (Alcalá de Henares, Madrid) and teachers (Amparo, Teresa, José) and principal (Víctor) of C.E.I.P. Maestra Plácida (Azuqueca de Henares, Guadalajara) who collaborated in the study.

Declaration of interest: No conflict of interest is declared by authors.

\section{REFERENCES}

Amabile, T. M. (1996). Creativity in context: Update to the social psychology of creativity. Routledge. https:/ / doi.org/10.4324/9780429501234

American Institute of Physics (2020). Children's misconceptions about science. "Operation physics", elementary-middle school physics education project. http://www.eskimo.com/ billb/miscon/opphys. html

Andersson, B., \& Bach, F. (2005). On designing and evaluating teaching sequences taking geometrical optics as an example. Science Education, 89(2), 196218. https:/ / doi.org/10.1002/sce.20044 
Aranzabal, J. G., Ametller, J., \& Elosegi, K. Z. (2021). Investigación basada en el diseño de secuencias de enseñanza-aprendizaje: Una línea de investigación emergente en enseñanza de las ciencias [Research based on the design of teaching-learning sequences: An emerging line of research in science teaching]. Revista Eureka sobre Enseñanza y Divulgación de las Ciencias [Eureka Magazine on Science Teaching and Dissemination], 18(1), 1801-1801. https://doi.org/ 10.25267/Rev_Eureka_ensen_divulg_cienc.2021.v1 8.i1.1801

Bransford, J., Bransford, J. D., Brown, A. L., \& Cocking, R. R. (1999). How people learn: Brain, mind, experience, and school. National Academies Press.

Bruner, J. S. (1966). Toward a theory of instruction. MA: Harvard University Press.

Burnard, P. (2012). Musical creativities in practice. Oxford: Oxford University Press. https:/ / doi.org/10.1093/ acprof:oso/9780199583942.001.0001

Buty, C., Tiberghien, A., \& Le Maréchal, J. F. (2004). Learning hypotheses and associated tools to design and to analyse teaching-learning sequences. International Journal of Science Education, 26, 579-604. https://doi.org/10.1080/09500690310001614735

Bybee, R. W., Taylor, J. A., Gardner, A., Van Scotter, P., Powell, J. C., Westbrook, A., \& Landes, N. (2006). The BSCS 5E instructional model: Origins and effectiveness. https:/ / media.bscs.org/bscsmw/5es/ bscs_5e_full_report.pdf

Castilla-La Mancha, Consejería de Educación, Cultura y Deportes (2020). Decreto 54/2014 of the 10th of June of 2014 [2014/9028]. Diario Oficial de CastillaLa Mancha, Año XXXIII Núm. 132, 11/07/2014, pp. 18498-18909 [Castilla-La Mancha, Ministry of Education, Culture and Sports (2020). Decree $54 / 2014$ of the 10th of June of 2014 [2014/9028]. Official Gazette of Castilla-La Mancha, Year XXXIII No. 132, 07/11/2014, pp. 18498-18909]. https:/ / www.educa.jccm.es/es/normativa/decre to-54-2014-10-07-2014-establece-curriculoeducacion-pr

Chevallard, Y. (1989). On didactic transposition theory: Some introductory notes. In Proceedings of the international symposium on selected domains of research and development in mathematics education (pp. 51-62). Bratislava, Czechoslovakia: Comenius University.

Chi, M. T., Bassok, M., Lewis, M. W., Reimann, P., \& Glaser, R. (1989). Self-explanations: How students' study and use examples in learning to solve problems. Cognitive Science, 13(2), 145-182. https: / / doi.org/10.1016/0364-0213(89)90002-5

Cobb, P., \& Gravemeijer, K. (2008). Experimenting to support and understand learning processes. In A. E. Kelly, R. A. Lesh, \& J. A. Baek (Eds.), Handbook of design research methods in education (pp. 68-95). Routledge.

Conradty, C., Sotiriou, S. A., Bogner, F. X. (2020). How creativity in STEAM modules intervenes with selfefficacy and motivation. Education Sciences, 10(3), 70. https:/ / doi.org/10.3390/educsci10030070

Craft, A. (2001). Little c creativity. In A. Craft, B. Jeffrey, \& M. Liebling (Eds.). Creativity in education (pp. 4561). Continuum.

Creswell, J. W., \& Creswell, J. D. (2017). Research design: Qualitative, quantitative, and mixed methods approaches. SAGE.

Design Based Research Collective (2003). Design-based research: An emerging paradigm for educational inquiry. Educational Researcher, 32(1), 5-8. https:/ / doi.org/10.3102/0013189X032001005

Driver, R. (1985). Children's ideas in science. McGraw-Hill Education (UK).

Duit, R. (2006). Science education research-An indispensable prerequisite for improving instructional practice. ESERA Summer School, Braga, 1-18.

Edelson, D. C. (2001). Learning-for-use: A framework for the design of technology-supported inquiry activities. Journal of Research in Science teaching, 38(3), 355-385. https://doi.org/10.1002/10982736(200103)38:3<355::AID-TEA1010>3.0.CO;2-M

Elliott, J. (2009). Building educational theory through action research. In S. E. Noffke, \& B. Somekh (Eds.), The SAGE handbook of educational action research (pp. 28-38). SAGE.

Escobar-Pérez, J., \& Cuervo-Martínez, Á. (2008). Validez de contenido y juicio de expertos: Una aproximación a su utilización [Content validity and expert judgment: An approach to its use]. Avances en Medición [Advances in Measurement], 6(1), 27-36. https:// www.academia.edu/download/48452857 / Articulo3_Juicio_de_expertos_27-36.pdf

García-Carmona, A., \& Criado, A. M. (2013). Enseñanza de la energía en la etapa 6-12 años: Un planteamiento desde el ámbito curricular de las máquinas [Teaching energy in the 6-12 year stage: An approach from the curricular field of machines]. Enseñanza de las Ciencias [Science Teaching], 31(3), 87102. https:/ / doi.org/10.5565/rev/ec/v31n3.772

García-Legaz, A. M. C., \& García-Carmona, A. (2011). Investigando las máquinas y artefactos [Investigating the machines and artifacts]. Díada Editora.

Glaveanu, V. P. (2018). Educating which creativity? Thinking Skills and Creativity, 27, 25-32. https:// doi.org/10.1016/j.tsc.2017.11.006

Glaveanu, V. P., \& Beghetto, R. A. (2021). Creative experience: A non-standard definition of creativity. 
Creativity Research Journal, 33(2), 75-80. https:// doi.org/10.1080/10400419.2020.1827606

Gomes, C. M. A., Golino, H. F., \& Menezes, I. G. (2014). Predicting school achievement rather than intelligence: Does metacognition matter? Psychology, 5(09), 1095-1110. https://doi.org/ 10.4236/psych.2014.59122

Gordon, J., Halász, G., Krawczyk, M., Leney, T., Michel, A., Pepper, D., Putkiewicz, E., \& Wiśniewski, J. (2009). Key competences in Europe: Opening doors for lifelong learners across the school curriculum and teacher education. CASE Network Reports, (87). https://doi.org/10.2139/ssrn.1517804

Hattie, J., \& Yates, G. C. (2013). Visible learning and the science of how we learn. Routledge. https:/ / doi.org/ 10.4324/9781315885025

Jiménez, J. R. (2006). Proyecto curricular INM (6-12): Un aula para la investigación [Curricular project INM (6-12): A classroom for research]. Sevilla, Díada.

Kortland K., \& Klaassen K. (2010). Designing theory-based teaching-learning sequences for science education. FSME, Utrecht.

Krajcik, J., McNeill, K. L., \& Reiser, B. J. (2008). Learninggoals-driven design model: Developing curriculum materials that align with national standards and incorporate project-based pedagogy. Science Education, 92(1), 1-32. https://doi.org/10.1002/ sce. 20240

Leach, J., \& Scott, P. (2002). Designing and evaluating science teaching sequences: An approach drawing upon the concept of learning demand and a social constructivist perspective on learning. Studies in Science Education, 38, 115-142. https://doi.org/ 10.1080/03057260208560189

Leach, J., Ametller, J., \& Scott, P. (2009). The relationship of theory and practice in designing, implementing and evaluating teaching sequences: Learning from examples that don't work. Éducation et Didactique [Education and Didactics], (3-2), 133-155. https://doi.org/10.4000/educationdidactique.497

Levy, P. (2017). Research design: Quantitative, qualitative, mixed methods, arts-based, and community-based participatory research approaches. The Guilford Press.

Lherer, R., \& Schaule, L. (1998). Reasoning about structure and function: Children's conceptions of gears. Journal of Research in Science Teaching, 35(1), 325. https://doi.org/10.1002/(SICI)1098-2736(1998 01)35:1<3::AID-TEA2>3.0.CO;2-X

Lijnse, P. L. (1995). "Developmental research" as a way to an empirically based "didactical structure" of science. Science Education, 79(2), 189-199. https://doi.org/10.1002/sce.3730790205

Loewenthal, K., \& Lewis, C. A. (2018). An introduction to psychological tests and scales (2nd Ed.).
Psychology Press. https://doi.org/10.4324/97813 15782980

Lubart, T., \& Thornhill-Miller, B. (2019). Creativity: An overview of the $7 C^{\prime}$ s of creative thought. Psychology of Human Thought, 279-306.

Martín, H. R. (2020). ¿Cómo aprendemos?: Una aproximación científica al aprendizaje y la enseñanza [How do we learn?: A scientific approach to learning and teaching]. Graó.

McClelland, M. M., \& Cameron, C. E. (2011). Selfregulation and academic achievement in elementary school children. New Directions for Child and Adolescent Development, 2011, 29-44. https:// doi.org/10.1002/cd.302

Méheut, M., \& Psillos, D. (2004). Teaching-learning sequences. Aims and tools for science education. International Journal of Science Education, 26(5), 515535.

https:/ / doi.org/10.1080/09500690310001614762

National Council of Teachers of Mathematics. (2000). Principles and standards for school mathematics. Reston, VA: Author.

Norbury, J. W. (2006). Working with simple machines. Physics Education, 41(6), 546-550. https://doi.org/ 10.1088/0031-9120/41/6/010

Pérez, S., \& Villagrá, J. Á. M. (2020). La competencia científica en las actividades de aprendizaje incluidas en los libros de texto de ciencias de la naturaleza [Scientific competence in the learning activities included in natural sciences textbooks]. Revista Eureka sobre Enseñanza y Divulgación de las Ciencias [Eureka Magazine on Science Teaching and Dissemination]. https://doi.org/10.25267/Rev_ Eureka_ensen_divulg_cienc.2020.v17.i2.2101

Plomp, T., \& Nieveen, N. (2007). An introduction to educational design research. In Proceedings of the seminar conducted at the East China Normal University, Shanghai (PR China) (Vol. 23).

Polya, G. (2004). How to solve it: A new aspect of mathematical method. Princeton University Press.

Psillos, D., \& Kariotoglou, P. (2015). Iterative design of teaching-learning sequences: introducing the science of materials in European schools. Springer. https:/ / doi.org/10.1007/978-94-007-7808-5

R Core Team (2018). R: A language and environment for statistical computing. R Foundation for Statistical Computing. Vienna. Austria. https://www.Rpro ject.org/

Ramírez, M. C., \& Cepena, M. C. M. (2012). Perfeccionamiento de un instrumento para la selección de expertos en las investigaciones educativas [Improvement of an instrument for the selection of experts in educational research]. Revista Electrónica de Investigación Educativa [Electronic Journal of Educational Research], 14(2), 167-179. 
https:/ / www.redalyc.org/ articulo.oa?id=1552501 3012

Sangoseni, O., Hellman, M., \& Hill, C. (2013). Development and validation of a questionnaire to assess the effect of online learning on behaviors, attitudes, and clinical practices of physical therapists in the United States regarding evidenced-based clinical practice. Internet Journal of Allied Health Sciences and Practice, 11(2), 7. https:/ / doi.org/10.46743/1540-580X/2013.1439

Sanmartí, N. (2002). Didáctica de las ciencias en la educación secundaria obligatoria [Science didactics in compulsory secondary education]. Síntesis S. A.

Schunk, D. H. (1989). Self-efficacy and achievement behaviors. Educational Psychology Review, 1(3), 173208. https:/ / doi.org/10.1007/BF01320134

Shayer, M., \& Adey, P. (1981). Towards a science of science teaching: Cognitive development and curriculum demand. Heinemann Educational Publishers.

Silver, E. A. (1997). Fostering creativity through instruction rich in mathematical problem solving and problem posing. Zentralblatt für Didaktik der Mathematik, 29, 75-80. https://doi.org/10.1007/ s11858-997-0003-x
Sinha, T., \& Kapur, M. (2021). When problem solving followed by instruction works: Evidence for productive failure. Review of Educational Research, 91(5), 761-798. https://doi.org/10.3102/00346543 211019105

Sternberg, R. J. (2005). Creativity or creativities? International Journal of Human Computer Studies, 63, 370-382. https:/ / doi.org/10.1016/j.ijhcs.2005.04.003

Sternberg, R. J., \& Lubart. T. I. (1993). Creative giftendness: A multivariate Investment approach. Gifted Child Quarterly, 37(1), 7-15. https:/ / doi.org/ $10.1177 / 001698629303700102$

Toma, R. B., \& Greca, I. M. (2018). The effect of integrative STEM instruction on elementary students' attitudes toward science. Eurasia Journal of Mathematics, Science and Technology Education, 14(4), 1383-1395. https:/ / doi.org/10.29333/ ejmste/83676

Tyler-Wood, T., Knezek, G., \& Christensen, R. (2010). Instruments for assessing interest in STEM content and careers. Journal of Technology and Teacher Education, 18(2), 345-368. 


\section{APPENDIX A}

\section{Learning Objectives of the TLS}

Education in Spain is compulsory for all pupils under 16. These studies are organised in three stages: Kindergarten (3-6 years), elementary education (6-12 years), and secondary education (12-16 years). The administrative organisation of Spain in seventeen Autonomous Communities, each of them having a certain authority on education. In our case, the objectives are taken from the official curriculum of the Community of Castilla-La Mancha, although they are essentially similar in other Communities (Castilla-La Mancha, Consejería de Educación, Cultura y Deportes, 2014). The list has been completed with other attitudinal objectives taken from García-Legaz and García-Carmona (2011).

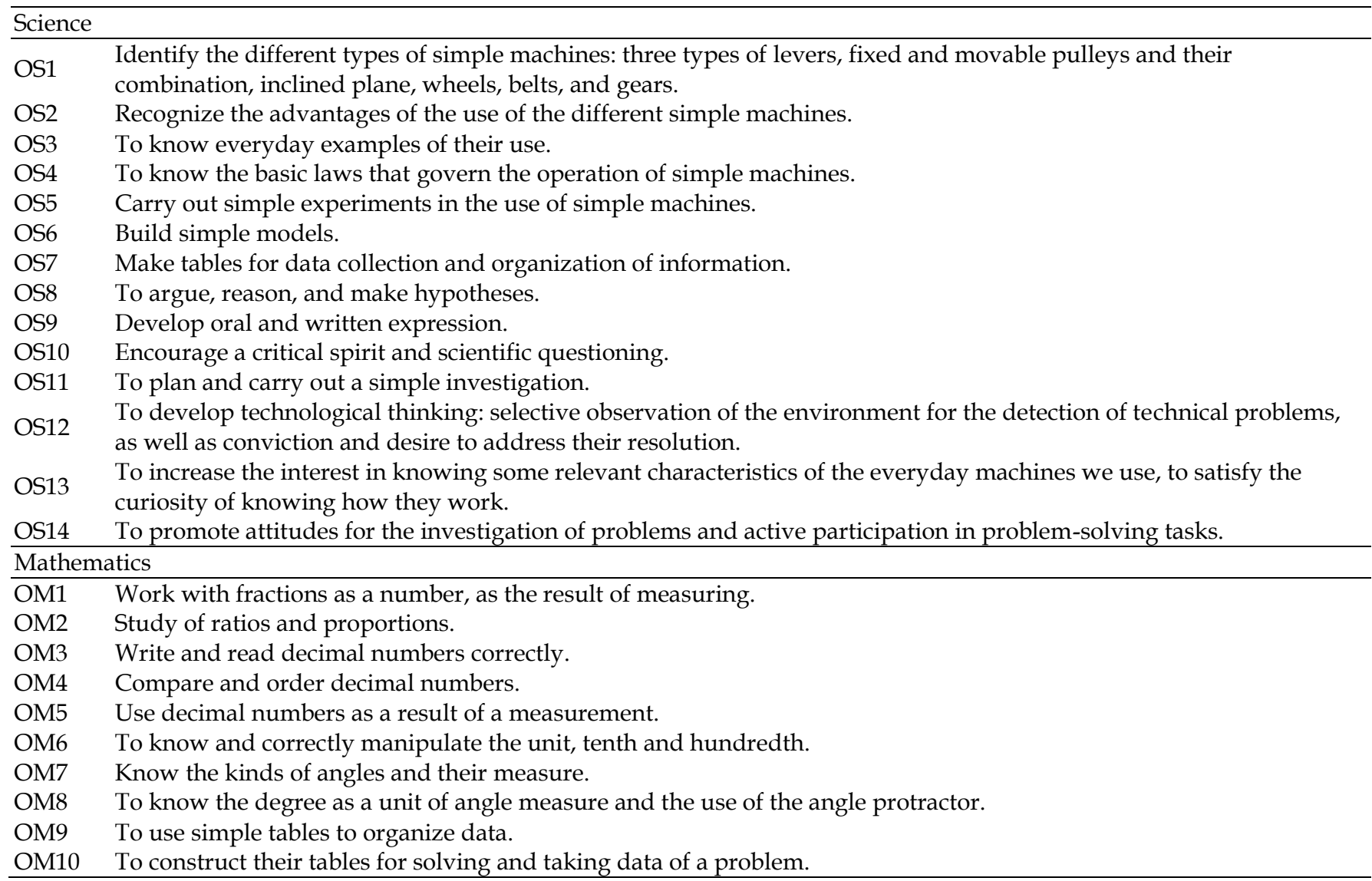




\section{APPENDIX B}

\section{The Designed TLS (Final Version)}

The worksheets created for the students along with the teacher's guide are available in English and Spanish. They are available by contacting the authors. Explanatory videos of the activities are could be seen at the Grupo ICC youtube channel: https://www.youtube.com/watch?v=afTMnJzg9o0

An $\left(^{*}\right)$ is used to indicate those activities that are considered suitable only for the older age groups (11-12 years).

\begin{tabular}{|c|c|c|c|}
\hline Activity & Contents & $\begin{array}{l}\text { Learning } \\
\text { objectives }\end{array}$ & $\begin{array}{l}\text { Conceptual } \\
\text { difficulties } \\
\text { addressed }\end{array}$ \\
\hline Session 1 & Introduction & OS13 & CD1 \\
\hline How did they build the great pyramids in Ancient Egypt? & Motivational & OS14 & CD2 \\
\hline $\begin{array}{l}\text { Session } 2 \\
\text { Explore various levers by analysing the influence of the } \\
\text { position of the fulcrum or the length of the arms through } \\
\text { guiding questions: how do you manage to lift the book with } \\
\text { only one finger? how do you manage to cut the toothpick more } \\
\text { easily? }\end{array}$ & $\begin{array}{c}\text { Levers } \\
\text { Elements: Fulcrum, bar, and lever } \\
\text { arms } \\
\text { Forces }\end{array}$ & $\begin{array}{c}\text { OS1 } \\
\text { OS2 } \\
\text { OS3 } \\
\text { OS5 } \\
\text { OS8 } \\
\text { OS9 } \\
\text { OS10 } \\
\text { OS11 } \\
\text { OS12 } \\
\text { OS13 } \\
\text { OS14 }\end{array}$ & CD6 \\
\hline $\begin{array}{l}\text { Session } 3 \\
\text { Recognize levers in everyday life: Wheelbarrows, pincers, a } \\
\text { human body, etc. } \\
\text { What are the advantages of using these levers? } \\
\text { How is force related to the size of the lever arms? } \\
\text { These concepts are explained with the help of videos. } \\
\text { Construction of a catapult }\end{array}$ & $\begin{array}{l}\text { First, second, and third class of } \\
\text { levers } \\
\text { Work: Force } x \text { distance } \\
\text { Mechanical advantage } \\
\text { Conservation of energy }\left(^{*}\right)\end{array}$ & $\begin{array}{l}\text { OS1 } \\
\text { OS2 } \\
\text { OS3 } \\
\text { OS4 } \\
\text { OS5 } \\
\text { OS6 } \\
\text { OS8 } \\
\text { OS9 } \\
\text { OS10 } \\
\text { OS11 } \\
\text { OS12 } \\
\text { OS13 } \\
\text { OS14 }\end{array}$ & $\begin{array}{l}\text { CD2 } \\
\text { CD6 } \\
\text { CD9 } \\
\text { CD10 } \\
\text { CD11 } \\
\text { PD1 }\end{array}$ \\
\hline 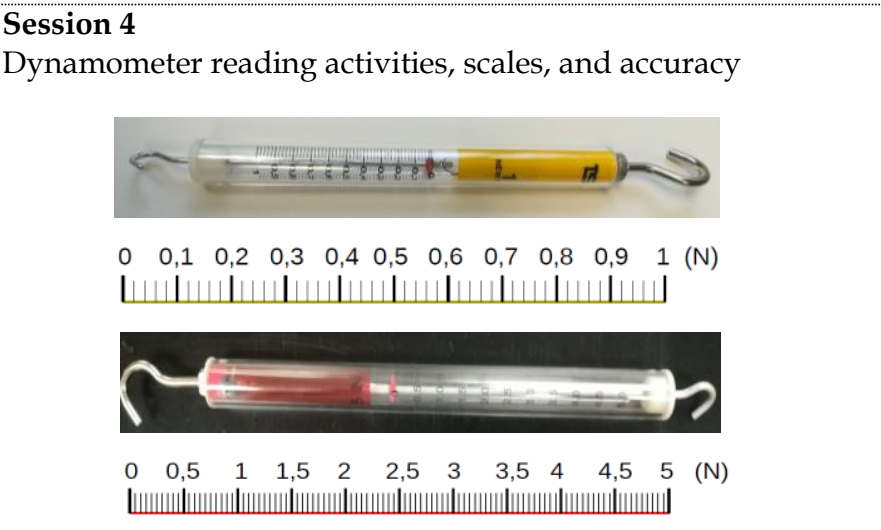 & $\begin{array}{l}\text { The dynamometer: } \\
\text { Use, scale, and accuracy } \\
\text { Measurement } \\
\text { Decimals }\end{array}$ & $\begin{array}{l}\text { OM3 } \\
\text { OM4 } \\
\text { OM5 } \\
\text { OM9 }\end{array}$ & PD2 \\
\hline
\end{tabular}




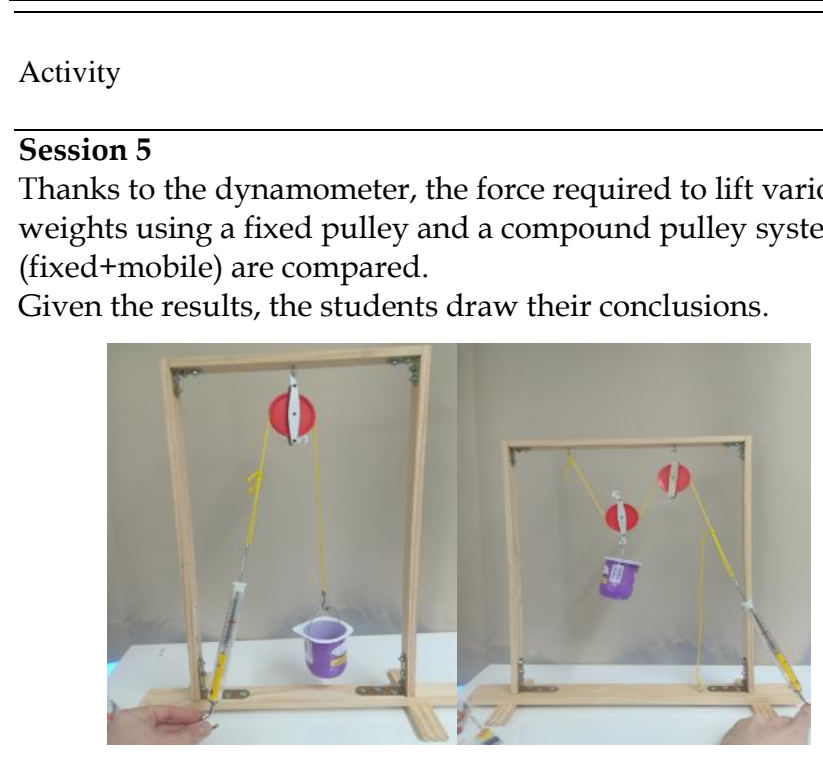

\section{Session 6}

Through an explanatory video and relating it to previous experiences, the different types of pulleys, the exchange of force per distance in each of them and their mechanical advantage are analysed.

Several examples from everyday life are observed (elevator, cranes, ships, factories, wells) and the use of a counterweight is discussed.

\section{Contents}

Simple fixed and movable pulley
Composite pulley
Organization of the information
in data tables
Use of the dynamometer

Use of the dynamometer
Learning

objectives
Conceptual

difficulties addressed

$\begin{array}{ll}\text { OS1 } & \text { CD7 } \\ \text { OS2 } & \text { CD8 } \\ \text { OS3 } & \text { PD1 } \\ \text { OS5 } & \text { PD2 } \\ \text { OS7 } & \text { PD3 }\end{array}$

OS9

OS10

OS11

OS12

OS13

OS14

OM3

OM4

OM5

OM9

OM10

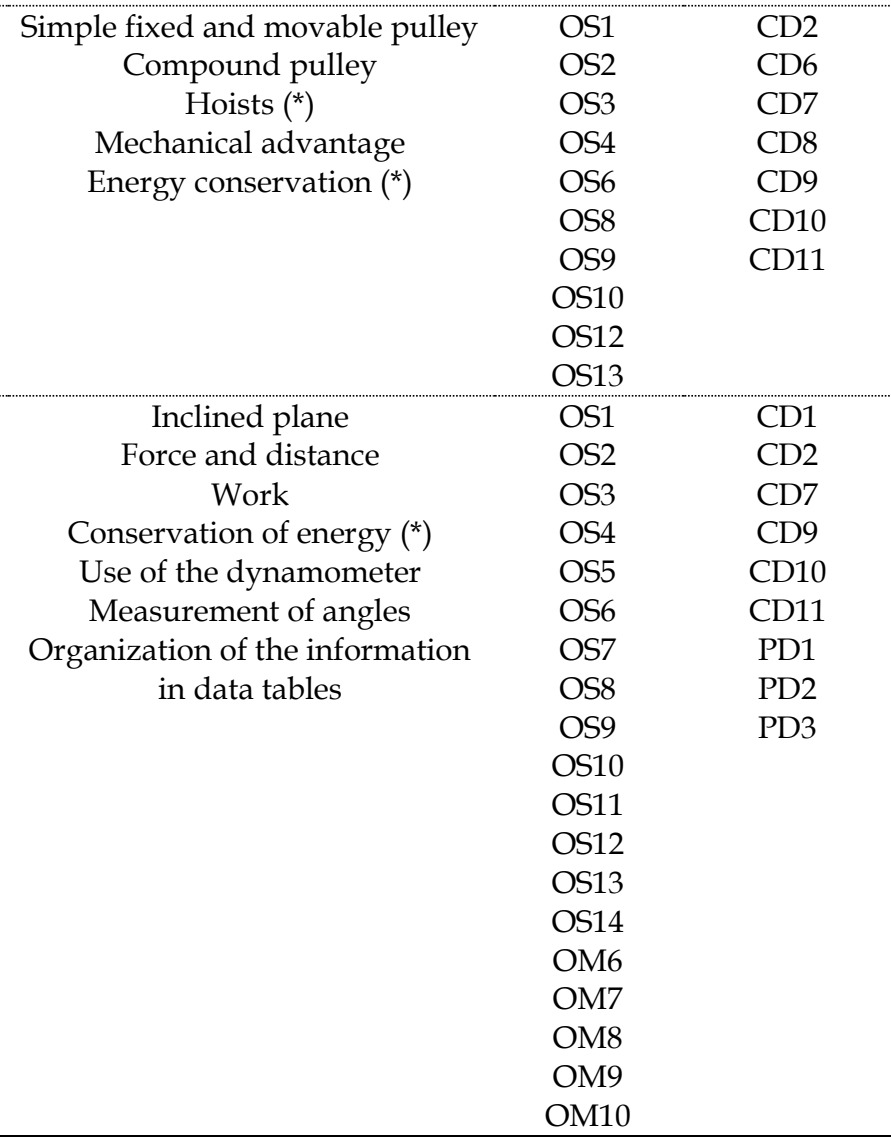




Activity
Session 8
Guiding questions:
How could the Egyptians drag those large blocks of stone?
What do you think a wheel is for? What is the use of an axle?
Do two wheels of the same or different sizes turn the same
way?

Contents

Wheels: Advantages and uses Discovery of the wheel Utility of an axle
Conceptual difficulties addressed

\section{Session 9}

Using Legos, students explore how the placement of the belt and the size of the wheels influence their direction and speed of rotation.
Learning objectives

OS1
OS2
OS3
OS5
OS8
OS9
OS10
OS11
OS12
OS13
OS14

CD1

$\mathrm{CD} 2$

PD1

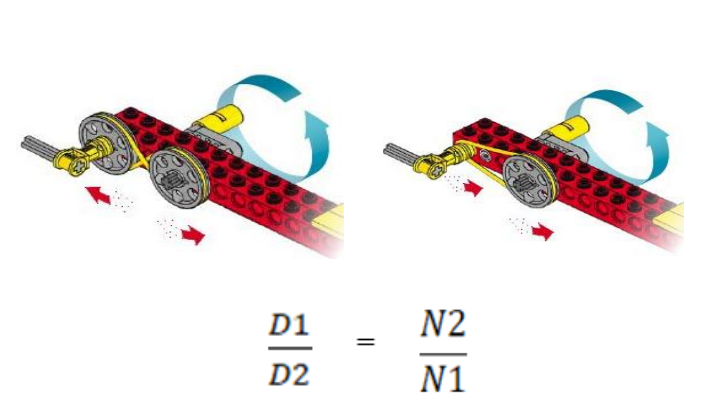

\section{Session 10:}

Guiding questions: How many turns does the second gear turn when you turn the crank? Which way do they turn? Various sizes and numbers of gears are combined.
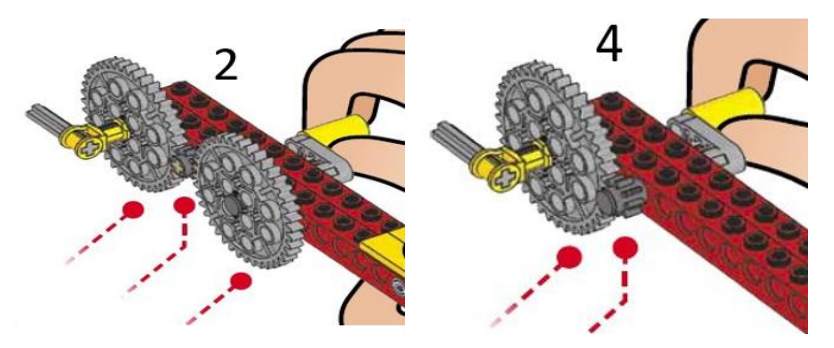

\section{Session 11}

From the number of teeth, the relationship with the number of turns of each wheel is checked.

$$
\frac{D 1}{D 2}=\frac{N 2}{N 1}
$$

A video explains the transmission of power through gears. The use of gears in various everyday objects (watches, toys, appliances) is observed.

Belts

Direction and speed of rotation

Use of fractions for the relation between the radius and the number of turns of the wheels

$\begin{array}{ll}\text { OS1 } & \text { CD7 } \\ \text { OS2 } & \text { CD10 } \\ \text { OS3 } & \text { CD11 } \\ \text { OS4 } & \text { PD1 }\end{array}$

OS5

OS6

OS8

OS9

OS10

OS11

OS12

OS13

OS14

OM1

OM2

OM9

$\begin{array}{cc}\text { Gears } & \text { OS1 } \\ \text { Direction and speed of rotation } & \text { OS2 } \\ \text { OS3 }\end{array}$

OS1
OS2
OS3

OS5

OS8

OS9

OS10

OS11

OS12

OS13

OS14

OM1

OM2

OM9

$\begin{array}{ll}\text { Gears } & \text { OS1 } \\ & \text { OS2 }\end{array}$

Use of fractions for the

OS3

relationship between the number of teeth and the number of turns

$$
\text { of gears }
$$

OS4

OS5

OS6

OS8

Mechanical advantage $\left(^{*}\right)$

OS9

OS10

Conservation of energy $\left(^{*}\right)$

OS11

OS12

OS13

OS14

OM1

OM2

OM9 


\begin{tabular}{|c|c|c|c|}
\hline Activity & Contents & $\begin{array}{c}\text { Learning } \\
\text { objectives }\end{array}$ & $\begin{array}{c}\text { Conceptual } \\
\text { difficulties } \\
\text { addressed }\end{array}$ \\
\hline \multirow{10}{*}{$\begin{array}{l}\text { Session } 12 \\
\text { Several simple machines are identified in some examples of } \\
\text { composite machines such as the bicycle or the crane. The case } \\
\text { of the bicycle is analysed in detail and how the combination of } \\
\text { sprockets, chain rings and the toothed belt makes it possible to } \\
\text { achieve great speed and displacement with little force. }\end{array}$} & Compound machines & OS1 & CD1 \\
\hline & Mechanical advantage & OS2 & CD2 \\
\hline & Combination of advantages in the & OS3 & CD5 \\
\hline & bicycle $(*)$ & OS4 & CD6 \\
\hline & & OS6 & CD11 \\
\hline & & OS8 & \\
\hline & & OS9 & \\
\hline & & OS10 & \\
\hline & & OS12 & \\
\hline & & OS13 & \\
\hline
\end{tabular}




\section{APPENDIX C}

\section{Modifications in Successive Iterations}

The following table summarizes the most relevant changes introduced after the first two iterations and their justification.

\begin{tabular}{|c|c|c|}
\hline Justification & Iteration 1 & Iteration 2 \\
\hline $\begin{array}{l}\text { Difficulties are observed in the } \\
\text { interpretation of the scales of the } \\
\text { different dynamometers. }\end{array}$ & $\begin{array}{c}\text { A specific session on the use of the } \\
\text { dynamometer is introduced (session } \\
4) .\end{array}$ & Some activities are reviewed. \\
\hline $\begin{array}{l}\text { To assist teachers in the explanation and } \\
\text { to show more everyday examples, } \\
\text { explanatory videos of various types of } \\
\text { machines are included. }\end{array}$ & $\begin{array}{l}\text { Videos used in sessions: 2, 6, 7, and } \\
\text { 11. All of them are available in Grupo } \\
\text { ICC youtube channel: } \\
\text { https:/ / www.youtube.com/ } \\
\text { watch?v=afTMnJzgoo0 }\end{array}$ & $\begin{array}{l}\text { Suggestions are added for teachers on } \\
\text { the most useful parts of these videos } \\
\text { according to the age of the students. }\end{array}$ \\
\hline
\end{tabular}

To enhance the application of what has been learned with the levers to a new context and to promote creativity and autonomy.

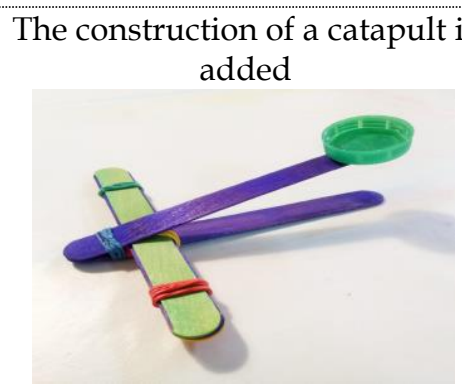

Problems of interpretation of the
$\begin{aligned} & \text { Wording and langue's of some of the } \\ & \text { questions is adapted }\end{aligned}$

Lack of time in the classroom
The device initially designed for
measuring angles in the inclined plane is
improved. The new one allows more
freedom to the students and thus it is
easier to check if they learn correctly how
to do it.

Conceptual difficulties with the concept of work and conservation of energy.
Some conceptual issues and questions are limited to the higher grades. These activities are indicated with $\left(^{*}\right)$ in the TLS (Appendix B).

Difficulties in the organization of information.
The tables are included in the worksheets where students should collect the information (Sessions 5 and 7).

\begin{tabular}{|c|c|c|}
\hline $\begin{array}{c}\text { Bolas en la } \\
\text { cesta }\end{array}$ & $\begin{array}{c}\text { Peso colgado } \\
(\mathrm{N})\end{array}$ & $\begin{array}{c}\text { Peso con la } \\
\text { polea }(\mathrm{N})\end{array}$ \\
\hline 1 & 1 & 0,5 \\
\hline 2 & 1,5 & 0,8 \\
\hline 3 & 2,3 & 1,2 \\
\hline
\end{tabular}




\begin{tabular}{|c|c|c|}
\hline Justification & Iteration 1 & Iteration 2 \\
\hline $\begin{array}{l}\text { Conceptual difficulties related to the } \\
\text { weight of objects }\end{array}$ & $\begin{array}{l}\text { Suggestions to alleviate some of them } \\
\text { are added in the Teacher's Guide. } \\
\text { Some examples of student errors: } \\
\text { Compound pulley: "The weight is } \\
\text { divided between the two pulleys." } \\
\text { Lever: "Its usefulness is to make } \\
\text { things weigh less." }\end{array}$ & Remains unchanged \\
\hline \multirow[t]{5}{*}{ Conceptual difficulty related to the gears } & \multirow[t]{5}{*}{$\begin{array}{l}\text { Questions are added to further guide } \\
\text { the student: } \\
\text { "If you turn the crank once, how } \\
\text { many turns does each gear turn?" } \\
\text { "Compare models } 3 \text { and 4." }\end{array}$} & $\begin{array}{l}\text { The student is more oriented towards } \\
\text { finding the relationship between the } \\
\text { number of turns and the number of } \\
\text { gears. } \\
\text { "Now write the result as a fraction." }\end{array}$ \\
\hline & & Número de vueltas del engranaje grande 1 \\
\hline & & Número de vueltas del engranaje pequeño $=\bar{S}$ \\
\hline & & Número de dientes del engranaje pequeño 8 \\
\hline & & $\overline{\text { Número de dientes del engranaje grande }} \overline{40}$ \\
\hline
\end{tabular}

\section{http://www.ejmste.com}

